
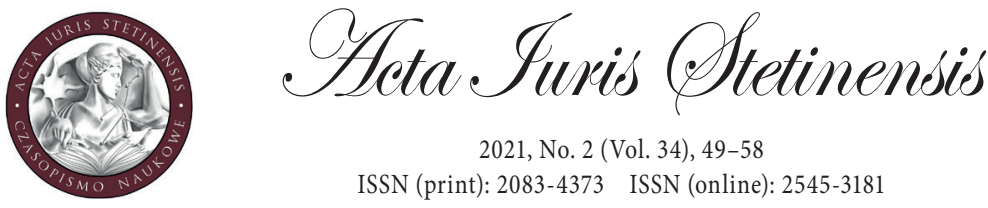

2021, No. 2 (Vol. 34), 49-58

ISSN (print): 2083-4373 ISSN (online): 2545-3181

DOI: $10.18276 /$ ais.2021.34-03

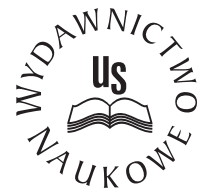

Jacek Krystek

Ph.D.

Lodz University of Technology, Poland

e-mail: jacek.krystek@p.lodz.pl

OPEN ACCESS

ORCID: 0000-0002-7251-9675

\title{
Formal requirements for authors of project information cards
}

\begin{abstract}
The formal requirements for authors of environmental impact assessment reports have changed over time. At present, such authors are required to demonstrate specific education or professional experience. A project information card is a similar document to an impact assessment report, drafted during an environmental impact assessment. Unlike in the case of impact assessment reports, at present, authors of project information cards are not obliged to meet any formal requirements.

Despite the different formal requirements applicable, both these documents can constitute grounds for issuing decisions on environmental conditions. This may allow circumvention of the main idea behind introducing formal requirements for authors of environmental impact assessment reports, i.e. the improvement in the quality of environmental studies. Therefore, if legal regulations require authors of environmental impact assessment reports to meet certain formal requirements, why should the same requirements not be demanded from authors of information cards which form the grounds for issuing decisions on environmental conditions?
\end{abstract}

Keywords: environmental impact assessment, project information card, environmental impact assessment report 


\section{Introduction}

The Act on the Environmental Protection Law ${ }^{1}$ has introduced certain fundamental principles of environmental protection, including inter alia the principle of prevention and precaution (Article 6). The principle of prevention requires anyone who undertakes an activity which may have a negative effect on the environment to prevent such an effect. On the other hand, the principle of precaution requires anyone who undertakes an activity, the negative effect whereof on the environment has not been fully identified yet, to take all possible preventive measures. Therefore, apart from "prevention", this indicates also "counteraction", "avoidance" and "protection". Mechanisms introduced into the environmental protection law to implement these principles include the system of environmental impact assessments. At present, the operation of the system is regulated by the Act on the provision of information on the environment and its protection, public participation in environmental protection and on environmental impact assessments. ${ }^{3}$ The Act requires every major project to be assessed in terms of its potential impact on the environment. Types of projects which require either an obligatory or optional assessment are enumerated in the Regulation of the Council of Ministers on projects likely to have significant effects on the environment. ${ }^{4}$ Conducting an environmental impact assessment requires preparation of a project information card or an environmental impact assessment report.

\section{Environmental impact assessment procedures}

The environmental impact assessment procedure involves cooperation between various public administration authorities aimed at issuing a decision on environmental conditions - the ultimate effect of the procedure. ${ }^{5}$ How this procedure is structured depends largely on the type of the project. There are projects that may always have a significant impact on the environment, which are categorised as

1 Act of 27 April 2001 on the Environmental Protection Law (Dz.U. (Journal of Laws) of 2020, item 1219 , as amended).

2 M. Górski et al., Prawo ochrony środowiska, Warszawa 2009, p. 59.

3 Act of 3 October 2008 on the provision of information on the environment and its protection, public participation in environmental protection and environmental impact assessments, Dz.U. (Journal of Laws) 2020, item 283, as amended (hereinafter the EIA Act).

4 Regulation of the Council of Ministers of 10 September 2019 on projects likely to have significant effects on the environment, Dz.U. (Journal of Laws) of 2019, item 1839.

5 B. Rakoczy et al., Oceny oddziaływania na środowisko w praktyce, Warszawa 2017, pp. 81-125. 
Group I projects, and ones that may potentially have a significant impact on the environment, which are categorised as Group II projects. An environmental impact assessment may be required also for projects that may have a significant impact on Nature 2000 areas which are not directly related to the protection of those areas or do not arise therefrom. Some authors refer to them as Group III projects. ${ }^{6}$

A decision on environmental conditions for group I projects can be issued when environmental impact assessment report has met requirements set forth in Article 66 of the EIA Act. In such a situation, one may request the authority in charge of the procedure to define the scope of the report before embarking on preparing it. A request to define the scope of the report should include a project information card which should meet the requirements set forth in Article 62a of the EIA Act.

For Group II projects, an investor applying for a decision on environmental conditions should submit a project information card. On obtaining opinions and agreements from other authorities, the authority in charge of the procedure may either directly issue the decision on environmental conditions when the expected impact is negligible or issue a decision that an environmental impact assessment is required and thus a relevant environmental impact assessment report must be prepared. The latter decision includes definition of the scope of the report. The procedure applied to Group III projects is very similar to the one applied to Group II projects.

In the event that an environmental impact assessment report is to be prepared, a public participation procedure is also obligatory.

A similar procedure is defined in Article 4 Directive 2011/92/EU of the European Parliament and of the Council on the assessment of the effects of certain public and private projects on the environment. ${ }^{7}$ In the event that an environmental impact assessment is required, the developer shall ensure that the environmental impact assessment report for the project is prepared by competent experts. There is no such requirement for the author of the project information card regarding undertakings from group II.

6 M. Pchałek, M. Behnke, Postępowanie w sprawie oceny oddzialywania na środowisko w prawie polskim i UE, Warszawa 2009, pp. 70-71.

7 Directive 2011/92/EU of the European Parliament and of the Council of 13 December 2011 on the assessment of the effects of certain public and private projects on the environment (OJ L 026, 28.1.2012, p. 1). 


\section{Probative value of the information card and environmental impact assessment report}

Since preparation of a project information card and/or an environmental impact assessment report is obligatory in the course of the environmental impact assessment procedure, one needs to consider the importance of these documents. It should be emphasised that their preparation is commissioned and financed by the investor who is planning the project.

Joanna Sliwa ${ }^{8}$ has analysed the importance of the environmental impact report as evidence in the procedure leading to the issuance of a decision on environmental conditions. As transpires from there reflections, the report should be a scientific study that analyses the required variants of execution of the intended project. Furthermore, although it is a private document, it should not be considered synonymous with an expert opinion as defined in Article 84(1) of the Code of Administrative Procedure. ${ }^{9}$

The role and importance of the environmental impact assessment report in the procedure leading to the issuance of a decision on environmental conditions has been examined also by administrative courts. The Supreme Administrative Court ${ }^{10}$ considered that "the report in the procedure regarding environmental conditions permit for a project is private evidence which nevertheless has special probative value. Its special character arises in particular from a comprehensive assessment of the project and analysis of the technological, legal, organisational and logistic aspect of the project combined." Similar decisions have been made also in other cases. ${ }^{11,12}$ Neither the administrative authority in charge of the procedure nor an administrative court alone can assess the content of the report, for such an assessment requires special knowledge of specific fields of science. They are only supposed to verify whether the report is complete and coherent, and thus meets

8 J. Śliwa, Raport oddziatywania na środowisko jako dowód w postępowaniu w sprawie oceny oddziaływania na środowisko, "Samorząd Terytorialny" 2015, No. 9, p. 23-41.

9 Act of 14 June 1960-Code of Administrative Procedure, Dz.U. (Journal of Laws) of 2021, item 735 , as amended.

10 Judgement of the Supreme Administrative Court of 11 July 2013, file no II OSK 639/13, LEX No. 1369033.

11 Judgement of the Supreme Administrative Court of 9 October 2018, file no II OSK 2533/16, LEX No. 2571946.

12 Judgement of the Supreme Administrative Court of 12 November 2019, file no II OSK 3179/17, LEX No. 2755218. 
the requirements set forth in Article 66 of the EIA Act. ${ }^{13}$ The party that challenges the findings of an environmental impact assessment report submitted by an investor may do so by presenting an equally professional study to the contrary. ${ }^{14}$ Such a professional study should be prepared by an expert who will either demonstrate that the report contains incorrectly collected or used data, or present other data acquired by himself/herself. ${ }^{15}$

A project information card is also a private document. ${ }^{16}$ It is the obligation of respective authorities to assess whether it is of any use for resolving the matter concerned. In particular, such an assessment ought to establish whether the card contains all the required elements and whether it correctly describes the activities intended by the investor. In general, the findings shown in an information card can be challenged only by means of presenting a new analysis which has been prepared by experts whose expertise corresponds to the expertise of the authors of the information card and which could demonstrate findings to the contrary of the findings contained in the information card. ${ }^{17}$

\section{Authors of environmental impact assessments}

As can be seen, authors of project information cards and environmental impact assessment reports should be experts who have the required expertise. A question arises here, how should such expertise and skills be documented? This matter has changed over time.

Under the 1980 Act on environmental protection and shaping ${ }^{18}$, the administrative authority was allowed to demand the investor as well as the owner or manager of a facility or a group of facilities to submit an expert opinion regarding the impact of the project or the facility/group of facilities on the environment. Allowed

13 Judgement of the Provincial Administrative Court in Warsaw of 10 April 2018, file no II SA/Wa 1357/17, LEX No. 2522386.

14 Judgement of the Provincial Administrative Court in Gorzów Wielkopolski of 19 December 2019, file no II SA/Go 434/19, LEX No. 2768042.

15 Judgement of the Provincial Administrative Court in Wrocław of 9 January 2018, file no II SA/Wr 487/17, LEX No. 2457686.

16 Judgement of the Provincial Administrative Court in Poznań of 17 January 2018, file no II SA/Po 625/17, LEX No. 2444298.

17 Judgement of the Supreme Administrative Court of 19 December 2017, file no II OSK 713/16, LEX No. 2435556.

18 Act of 31 January 1980 on environmental protection and shaping, Dz.U. (Journal of Laws) of 1980, No. 3, item 6. 
to prepare such opinions were higher education establishments, scientific entities, scientific research institutes, scientific associations and natural persons listed in the register of experts kept by the Minister of Administration, Local Economy and Environmental Protection. In the 1989 amendment to the Act on environmental protection and shaping ${ }^{19}$ the term "opinion" was replaced by "impact assessment." Additionally, the Minister of Environmental Protection and Natural Resources was authorised to establish, by means of a regulation, the requirements to be met by the impact assessment of a project, a facility or a group of facilities and design solutions likely to adversely affect the environment. Another amendment to the Act on environmental protection and shaping introduced in 1993 replaced the term "expert" by the term "an expert from the list of experts of the Minister of Environmental Protection, Natural Resources and Forestry," and the Minister of Environmental Protection, Natural Resources and Forestry was authorised to establish the requirements to be met by experts from the list of experts and the method of attesting these requirements. The Act on the provision of information on the environment and its protection and on environmental impact assessments, ${ }^{20}$ passed in 2000, removed the obligation for authors of impact assessments to hold any qualifications. It did not include the term "project information card," but defined the "information on the intended project", which also could be prepared by anyone. The Act was made obsolete in 2001 by the said Act on the Environmental Protection Law. In 2008, matters of access to environmental information, public participation in environmental protection and environmental impact assessments were transferred to the EIA Act. Still, no qualifications were required of authors of environmental impact assessment reports or information cards. As highlighted by Krzysztof Gruszecki ${ }^{21}$ in his commentary to the EIA Act, had the legislator wished to require that the document should be prepared by persons who met specific formal requirements, it would have regulated that matter in a clear manner. It was only the 2015 amendment to the EIA Act that introduced, effective on 1 January 2017, the requirement for authors of impact assessment reports to hold either formal (adequate education) or non-formal (professional experience) qualifications to be

19 Act of 27 April 1989 amending the Act on environmental protection and shaping and the Water Law, Dz.U. (Journal of Laws) of 1989, No. 26, item 139.

20 Act of 9 November 2000 on the provision of information on the environment and its protection and on environmental impact assessments, Dz.U. (Journal of Laws) of 2000, No. 109, item 1157.

21 K. Gruszecki, Ustawa o udostępnianiu informacji o środowisku i jego ochronie, udziale społeczeństwa $w$ ochronie środowiska oraz o ocenach oddziaływania na środowisko. Komentarz, Warszawa 2009, p. 182. 
entitled to prepare impact assessment reports. ${ }^{22}$ These documents may be prepared by - and in the case of teams of authors, the team may be led by - a person who completed, as defined by the laws on higher education, at least first or second-cycle study programmes, or long-cycle Master's programmes with education-related majors in the following areas:

a) exact sciences in the field of chemical sciences;

b) natural sciences in the fields of biology and Earth science;

c) technical sciences in the field of technical sciences including biotechnology, mining, geological engineering, environmental engineering;

d) agricultural, forestry and veterinarian sciences in the fields of agricultural and forestry sciences.

Also, environmental impact assessment reports may be authored and teams of authors may be led by persons who have completed, within the meaning of the laws on higher education, at least first or second-cycle study programmes or long-cycle Master's programmes and have at least 5 years of experience in working in teams that prepare environmental impact reports or environmental impact forecasts, have participated in preparing at least five environmental impact reports or five environmental impact forecasts. ${ }^{23}$ In September 2019, an amendment to the EIA Act entered into force ${ }^{24}$ reducing the required experience period from 5 to 3 years.

Furthermore, the author of an impact assessment report or the team leader must declare in his/her report that he/she meets the aforementioned requirements. Under the said declaration, the author must include the following clause: "I am aware of the criminal liability for submitting a false declaration" and his/her signature.

And what are the requirements that authors of project information cards must meet? Since the EIA Act does not define any formal or non-formal requirements in that respect, such documents may be prepared by anyone. Thus, the author of a project information card does not have to submit any declaration.

22 Act of 9 October 2015 amending the Act on the provision of information on the environment and its protection, public participation in environmental protection and on environmental impact assessments and amending certain other acts, Dz.U. (Journal of Laws) of 2015, item 1936, as amended.

23 J. Krystek, Raporty ooś po nowemu, "Przegląd Komunalny" 2016, No. 7(298), pp. 16-17.

24 Act of 19 July 2019 amending the Act on the provision of information on the environment and its protection, public participation in environmental protection and on environmental impact assessments and amending certain other acts, Dz.U. (Journal of Laws) of 2019, item 1712. 


\section{Conclusions}

Project information cards can be seen to have grown in volume over the recent years. While normally several pages long and containing basic project data some 10 years ago, they are now very complex, contain several dozen pages and discuss matters which previously were discussed only in impact assessment reports. This trend results from the fact that if a project information card for a Group II project sufficiently proves that no significant adverse impact on the environment can be expected, then the relevant decision on environmental conditions may be issued without the need to prepare an impact assessment report and, consequently, without the need to conduct the public participation procedure. This normally offers a significant reduction in the duration of the procedure and shortens the time of waiting for the environmental decision.

This is why some project information cards now include project variant analyses and even mathematical models of pollution emissions (usually air and noise emissions). Thus, project information cards have become a popular substitute of the environmental impact assessment reports. However, while the author of an environmental impact assessment report must hold the formal or non-formal qualifications required under the EIA Act, a person preparing a project information card is not required to meet any requirements whatsoever.

Thus, a special role in the environmental impact assessment precedence is assigned to the authority conducting the proceedings, which must assess whether the information provided in the project information sheet is sufficient to conclude that it will not be necessary to conduct a detailed impact assessment, including the need to prepare an impact assessment report. It should be remembered that the employees of the administration body usually do not have the competence of experts. In this context, it is worth quoting an excerpt from the judgment of the Provincial Administrative Court in Kraków, ${ }^{25}$ which ruled that "If, on the basis of the project information cards, it can be stated that the intended project will not have a significant impact on the environment, it is not necessary to duplicate this information in the impact assessment report. It is important that the body conducting the proceedings has clearly established that the condition of the environment will not deteriorate after the investment is implemented, and not the way in which these arrangements were made." As the information sheet is a private document, it is for the administration to assess whether it is a reliable document. Therefore, the

25 Judgement of the Provincial Administrative Court in Kraków of 5 April 2019, file no II SA/Kr 1632/18, LEX No. 2651844. 
administrative body is responsible for deciding whether the project information card is actually reliable or whether it only looks so.

Introduction of the formal requirements for authors of impact assessment reports, as argued in the statement of reasons for the amendment to the EIA Act, ${ }^{26}$ was meant to be "a response to the practice of preparing low quality documentation in the procedure of issuing decisions on environmental conditions." Another reason is to ensure compliance with Article 5(3)(a) of Directive 2011/92/EU, i.e. "to ensure completeness and quality of a report on environmental impact of a project, the contractor shall ensure that the report is prepared by adequately qualified experts."

The current trend to prepare extensive project information cards may become a means to circumvent the idea behind the amendment to the EIA Act which was designed to improve the quality of environmental documentation. Although the environmental impact assessment report remains the fundamental study prepared in the course of the environmental impact assessment procedure, the information card is, somewhat unexpectedly, taking its place, becoming the basis for decisions on environmental conditions. However, the extensiveness alone does not always give reliability and adequate quality to the documentation.

However, doubts may arise as to whether the introduction of formal requirements from the authors of project information cards will result in increasing their prices and make it more difficult for developers. It should not be obligatory, as the number of students graduating from Polish universities every year - entitled to prepare such documents - is significant. Secondly, there is also the way of acquiring rights as a result of work on environmental impact assessment reports. Of course, in the latter situation, work on project information cards should count on the experience of a given author.

Therefore, if legal regulations require authors of environmental impact assessment reports to meet certain formal requirements, then the same requirements should be asked of authors of information cards which form the grounds for issuing decisions on environmental conditions.

This article is an attempt to start a discussion, whether another amendment to the Act on the provision of information on the environment and its protection, public participation in environmental protection and on environmental impact

26 Statement of reasons concerning a draft amendment to the Act on the provision of information on the environment and its protection, public participation in environmental protection and on environmental impact assessments, Sejm Document No. 3677, the Sejm of the Republic of Poland, http://orka.sejm.gov.pl/Druki7ka.nsf/0/18253651381D2EF5C1257E840045298D/\%24File/3677. pdf (accessed 21.05.2020). 
assessments is required, so that authors of project information cards should meet the same requirements as authors of environmental impact assessment reports. Naturally, the current solution is absolutely adequate provided that the project information card is only an initial document and the impact assessment report will indeed be prepared further in the process. However, as the information card becomes the basis for issuing decisions on environmental conditions, thus in fact substituting the impact assessment report, why should the same requirements not be demanded from authors of information cards which form the grounds for issuing decisions on environmental conditions?

\section{References}

Górski M., et al., Prawo ochrony środowiska, Warszawa 2009.

Gruszecki K., Ustawa o udostępnianiu informacji o środowisku i jego ochronie, udziale społeczeństwa w ochronie środowiska oraz o ocenach oddzialywania na środowisko. Komentarz, Warszawa 2009.

Krystek J., Raporty ooś po nowemu, "Przegląd Komunalny" 2016, No. 7(298).

Pchałek M., Behnke M., Postępowanie w sprawie oceny oddziatywania na środowisko w prawie polskim i UE, Warszawa 2009.

Rakoczy B., Karpus K., Klimek G., Mierkiewicz M., Szalewska M., Szuma J., Szuma K., Wesołowska K., Oceny oddziaływania na środowisko w praktyce, Warszawa 2017.

Śliwa J., Raport oddzialywania na środowisko jako dowód w postępowaniu w sprawie oceny oddziatywania na środowisko, "Samorząd Terytorialny" 2015, No. 9.

\section{CITATION}

Krystek J., Formal requirements for authors of project information cards, "Acta Iuris Stetinensis" 2021, No. 2 (Vol. 34), 49-58, DOI: 10.18276/ais.2021.34-03. 